\title{
PENAFSIRAN SISTEMATIS TERHADAP KONSEP “SETIAP ANAK” BERHAK UNTUK MENGETAHUI ORANG TUANYA DALAM PASAL 1 AYAT (1) UNDANG UNDANG NO. 23 TAHUN 2002 TENTANG PERLINDUNGAN ANAK
}

\author{
Trusto Subekti \\ Fakultas Hukum Universitas Jenderal Soedirman \\ E-mail: trusto.subekti@unsoed.ac.id
}

\begin{abstract}
Partial understanding about children and their rights according to Law No. 1 of 1974 and Law no. 23 of 2002, become confusing. If the concept of "every child" has the right to know his parents, raised and nurtured by the parents themselves are connected with the concept of illegitimate children, there will arise the question of whether an illegitimate child ("child adultery"), may file a lawsuit to the Court, in case the biological father has been married to another woman. The result of systematic interpretation in the application of Article 7 paragraph (1) Act No. 23 of 2002 based on the principles and specific legal principles in family law and marriage, the recognition of children can not be applied to "every child" and it only works for children out of wedlock with her biological father is not bound by the terms of marriage with another woman. The expected contribution is the implementation of human rights in every national legal product should consider the principle of legal certainty, usefulness and fairness, and not just create new problems in society.
\end{abstract}

Key words: systematic interpretation, every child, child recognition

\begin{abstract}
Abstrak
Pemahaman secara partial mengenai anak dan hak-haknya menurut UU No. 1 Tahun 1974 dan UU No. 23 Tahun 2002, justru akan membingungkan. Apabila konsep "setiap anak" berhak mengetahui orang tuanya, dibesarkan dan diasuh oleh orang tuanya sendiri dihubungkan dengan konsep anak tidak sah, maka akan timbul permasalahan apakah seorang anak tidak sah ("anak zinah"), dapat mengajukan gugatan ke Pengadilan, pada hal ayah biologisnya telah terikat perkawinan dengan perempuan lain. Upaya memahami maksud dan isi sesuatu pasal undang-undang menggunakan suatu instrumen yang disebut penafsiran hukum, antara lain: penafsiran menurut bahasa dan penafsiran sistematis. Hasil penafsiran sistematis dalam penerapan Pasal 7 ayat (1) UU No. 23 Tahun 2002 didasarkan atas prinsip-prinsip dan asas-asas hukum khusus dalam Hukum Keluarga dan perkawinan, pengakuan anak tidak bisa diterapkan pada "setiap anak" dan hanya dapat dilakukan untuk anak luar kawin dengan syarat ayah biologisnya tidak terikat perkawinan dengan seorang perempuan lain. Kontribusi yang diharapkan adalah implementasi HAM dalam setiap produk hukum nasional seyogyanya memperhatikan asas kepastian hukum, kemanfaatan dan keadilan, dan tidak justru menimbulkan masalah baru dalam masyarakat.
\end{abstract}

Kata kunci: penafsiran sistematis, setiap anak, pengakuan anak

Pendahuluan

Penjelasan Umum Undang-Undang No. 23

Tahun 2002 Tentang Perlindungan Anak (selanjutnya ditulis UU No. 23 Tahun 2002) menyebutkan bahwa dalam perspektif hak asasi manusia didalamnya juga dikandung hak asasi anak. Selain itu anak juga mempunyai keduduk- an yang khas sebagai masa depan bangsa, perlakuan masyarakat terhadap anak dapat dijadikan cermin bagaimana bangsa itu membentuk masa depannya. Nilai-nilai sosial dan moral yang menjadi pegangan masyarakat dan bangsa 
diteruskan anak sebagai generasi penerus, ${ }^{1}$ oleh karena itu setiap anak berhak atas kelangsungan hidup, tumbuh, dan berkembang, berpartisipasi serta berhak atas perlindungan dari tindak kekerasan dan diskriminasi serta hak sipil dan kebebasan.

Pembentukan UU No. 23 tahun 2002 didasarkan pada pertimbangan bahwa perlindungan anak merupakan bagian dari kegiatan pembangunan nasional, khususnya dalam memajukan kehidupan berbangsa dan bernegara dan merupakan salah satu bentuk pengakuan atas hak asasi manusia dalam sistem hukum yang disepakati bersama, haruslah dipertahankan, dibangun, dikembangkan, dan dipelihara terus dalam situasi dan waktu apapun. ${ }^{2}$ Undang Undang ini dapat juga diartikan sebagai bentuk respon terhadap kesan di sementara masyarakat internasional bahwa Indonesia kurang peka terhadap masalah HAM, dengan dilakukannya berbagai langkah pembenahan baik secara hukum maupun kelembagaan. ${ }^{3}$ Hak asasi manusia merupakan hak yang melekat pada setiap induvidu begitu ia dilahirkan kedunia, dan hak ini akan tetap melekat pada diri manusia sepanjang hayatnya, namun dalam perjalanan kehidupan manusia ada kemungkinan terjadi kepemilikan hak asasinya menjadi terganggu oleh hadirnya kepentingan lainnya. ${ }^{4}$ Maka perlindungan hukum terhadap hak asasi manusia merupakan upaya yang secara terus menerus harus dimajukan sebagai sebuah tuntutan dari masyarakat modern, demokratis dan beradab. Problemanya, dalam implementasinya sangat dipengaruhi oleh situasi sosial, politik dan budaya serta hukum dimana hak asasi manusia itu ditegakkan. Pendekatan normatif di dalam proteksi dan promosi hak asasi manu-

Sunaryo, "Perlindungan Hukum Atas Hak Asasi Manusia Bagi Anak Dalam Proses Peradilan Pidana", Jurnal Dinamika Hukum, Vo. 2 No. 2, Mei 2005, FH Unsoed Purwokerto, hlm. 89.

2 Masyhur Effendi, 2005, Perkembangan Dimensi Hak Asasi Manusia (HAM) dan Proses Dinamika Penyusunan Hukum Hak Asasi Manusia (HAKHAM), Bogor Selatan: Penerbit Ghalia Indonesia, hlm. 61.

3 Muladi, 2005, Hak Asasi Manusia, Hakekat, Konsep dan Implikasinya Dalam Perspektif Hukum dan Masyarakat, Bandung: PT Refika Aditama, hlm. Vii.

4 Hibnu Nugroho, "Perspektif HAM dalam Pembantaran", Jurnal Dinamika Hukum, Vol 5 No. 2 Mei 2005 FH Unsoed Purwokerto, hlm. 93. sia tidak akan terwujud secara memadai bila tidak didukung proses politik yang memiliki pemahaman dan kemauan menghormati martabat manusia. ${ }^{5}$

Mengenai perlindungan hukum terhadap anak, Fasli Jalal dengan mengutip Konsep UNICEF Tahun 1996 menyatakan bahwa dalam kebijakan strateginya di bidang perlindungan anak telah diidentifikasi adanya kondisi sulit yang dapat merugikan anak-anak, antara lain kehilangan keluarga dan/atau pengasuh utama secara permanen atau dalam proses hukum dan pengadilan. Hak asasi manusia tersebut diatas senantiasa dilindungi, dihormati, dipertahankan, dan tidak boleh diabaikan, dikurangi atau dirampas oleh siapapun, termasuk hak untuk mengembangkan kecerdasannya melalui pendidikan yang bermutu, baik melalui jalur sekolah maupun luar sekolah. ${ }^{6}$ Ditegaskan pula oleh Muhamad Kholid dengan menyitir apa yang dikemukakan oleh Barda Nawawi Arief, bahwa perlindungan hukum bagi anak dapat diartikan sebagai upaya perlindungan hukum terhadap berbagai kekerasan dan hak asasi anak (fundamental rights and freedoms of children), serta berbagai kepentingan yang berhubungan dengan kesejahteraan anak. ${ }^{7}$

Pengertian anak yang dirumuskan dalam UU No. 23 tahun 2002, adalah seseorang yang belum berusia 18 (delapan belas) tahun, termasuk anak yang masih dalam kandungan (Pasal 1). Salah satu dari hak anak telah dirumuskan bahwa anak berhak untuk mengetahui orang tuanya, dibesarkan, dan diasuh oleh orang tuanya sendiri (Pasal 7 ayat (1) UU No. 23 tahun 2002. Kemudian dijelaskan pada bagian penjelasan bahwa ketentuan mengenai setiap anak berhak untuk mengetahui siapa orang tuanya, dalam arti asal-usulnya (termasuk ibu susunya), dimaksudkan untuk menghindari terputusnya

Muhammad, R. Mihradi, "Penegakan Hukum dan Hak Asasi Manusia", Jurnal Keadilan, Vol.2 No. 2 Tahun 2002, hlm. 26.

6 Fasli Jalal, “Kebijakan Strategis Jangka Pendek Bidang Pendidikan Luar Sekolah Dan Pemuda Yang Berkaitan Dengan Hak Asasi Manusia”, Jurnal hukum dan HAM Bidang Pendidikan, Vol. 1 No. 1, Juni 2003, hlm. 52.

Muhamad Kholid, "Kebijakan Formulasi Sanksi Tindakan Terhadap Anak Yang Terkait Unsur Culpa dan Tindak Pidana”, Jurnal Ilmu Hukum, Vol. 1 No. 1, April 2009, hlm. 3. 
silsilah dan hubungan darah antara anak dengan orang tua kandungnya, sedangkan hak untuk dibesarkan dan diasuh orang tuanya, dimaksudkan agar anak dapat patuh dan menghormati orang tuanya

Ketentuan dalam UU No. 23 Tahun 2002 tidak menjelaskan mengenai apa interpretasi kata "setiap anak" dalam Pasal 7 ayat (1) UU No. 23 Tahun 2002 tersebut. Apabila konsep "setiap anak" berhak mengetahui orang tuanya, dibesarkan dan diasuh oleh orang tuanya sendiri dihubungkan dengan konsep anak tidak sah, maka akan timbul permasalahan apakah seorang anak tidak sah dalam kualifikasi anak zinah atau anak sumbang, dapat ditafsirkan termasuk dalam kualifikasi "setiap anak" yang dapat mengajukan gugatan ke Pengadilan dengan berdasar atas UU No. 23 tahun 2002.

\section{Pembahasan}

\section{Harmonisasi Peraturan Perundang-undangan}

Pembangunan hukum nasional akan di arahkan guna terwujudnya negara hukum yang adil dan demokratis melalui pembenahan sistem hukum dengan membentuk peraturan perundang-undangan yang aspiratif, dan berintikan keadilan serta kebenaran yang mengabdi pada kepentingan rakyat dan bangsa di dalam bingkai NKRI. ${ }^{8}$ Kemudian dalam proses pembuatan undang-undang secara materiil hukum yang dikehendaki diharapkan dapat mencerminkan nilai dari kehendak rakyatnya, dalam hal ini tujuan diaturnya perlindungan anak disesuaikan dengan hakekat pembangunan nasional yaitu membangun manusia seutuhnya. Tujuan perlindungan anak khusus dalam bidang hukum perdata, meliputi kedudukan anak, kekuasaan orang tua, perwalian dan adopsi. ${ }^{9}$

Perlindungan hukum di bidang hukum perdata ini merupakan aspek hukum keluarga, dengan demikian secara sistematis harus terdapat harmonisasi antara kaidah hukum dalam

8 Bomer Pasaribu, "Arah Pembangunan Hukum Menurut UUD 1945 Hasil Amandemnen Dari Program Legislasi Nasional Tahun 2007", Majalah hukum Nasional, Vol. 1, No. 1 , hlm. 165.

9 Ermania Widjayanti, "Aspek Hukum Perlindungan Anak", Jurnal Hukum Prioris, Vol. 1, No. 3, September 2007, hlm. 186-188.
Undang Undang No. 23 tahun 2002 dengan kaidah hukum keluarga dalam peraturan perundang-undangan lainnya. Harmonisasi hukum ini dapat dilakukan dengan melakukan kegiatan untuk menyelaraskan suatu kaidah hukum, yang dalam hal ini Undang Undang yang tersusun secara sistematis dalam suatu hierarkhi tergambar dengan jelas dalam pengertian bahwa Undang Undang merupakan bagian integral yang utuh dari keseluruhan sistem peraturan perundang-undangan. ${ }^{10}$ Selanjutnya juga dijelaskan oleh A.A. Oka Mahendra dengan menyitir Tatang M. Amirin, bahwa suatu peraturan perundang-undangan sebagai suatu sistem atau sub sistem dari sistem yang lebih besar tentu harus memenuhi ciri-ciri antara lain ada saling keterkaitan dan saling bergantung dan merupakan satu kebulatan yang utuh, disamping cirriciri lainnya. ${ }^{11}$

\section{Penafsiran Hukum Sebagai Instrumen Untuk memahami Kehendak Pembentuk Undang- Undang}

Upaya memahami maksud dan isi sesuatu pasal undang-undang menggunakan suatu instrumen yang disebut penafsiran hukum, dan penafsiran hukum ini merupakan kewajiban dari Hakim ${ }^{12}$. Metode penafsiran hukum menurut Sudikno Mertokusumo ada 6 (enam), yaitu: gramatikal, teleologis atau sosiologis, sistematis atau logis, historis, perbandingan hukum dan futuristis. ${ }^{13}$ Dalam kajian ini difokuskan pada penafsiran gramatikal dan penafsiran sistematis. Penafsiran gramatikal merupakan metode penafsiran menurut bahasa, susun kata atau bunyinya, ${ }^{14}$ dan penafsiran sistematis adalah menafsirkan undang-undang dengan jalan menghubungkannya dengan undang-undang lainnya. ${ }^{15}$

10 Oka A.A. Mahendra, "Harmonisasi dan Sinkronsasi RUU dalam Rangka Pemantapan dan Pembulatan Konsepsi”, Jurnal Legislasi Indonesia,Vol. 2, No. 3, September 2005, hlm. 124.

11 Ibid, hlm. 125.

12 Yudha Bhakti Ardhiwisastra, 2000, Penafsiran dan Konstruksi Hukum, Bandung; Alumni, hlm. 8.

13 Sudikno Mertokusumo, 1993, Bab-bab Tentang Penemuan Hukum, Bandung: PT Citra Aditya Bakti, hlm. 14.

14 Ibid, hlm. 14-15.

15 Ibid, hlm. 16-17. 
Perlu dipahami bahwa undang-undang merupakan seperangkat kaedah yang didasarkan atas satu kebulatan alam pikir, secara substantial dapat dipahami melalui asas-asas yang melegitimasi hubungan antara satu pasal/ undang-undang dengan pasal/undang-undang lainnya. Asas hukum berperan sebagai pembentuk sistem, dan sering terjadi adanya kaedah hukum yang saling berlawanan maka akan saling mengendalikan atau membatasi dan dengan demikian akan ada dalam keseimbangan. ${ }^{16}$ Perlu dipahami pula apa yang dikemukakan oleh Bellefroid bahwa asas hukum adalah norma dasar yang dijabarkan dan berasal dari aturan-aturan yang lebih umum, dan asas hukum juga merupakan pengendapan hukum positif dalam suatu masyarakat; ${ }^{17}$ dan dalam pengertian lain asas hukum adalah prinsip-prinsip yang dianggap dasar atau pengertian dan nilai-nilai yang menjadi titik tolak berpikir tentang hukum atau titik tolak bagi pembentukan undang-undang dan interpretasi undangundang atau prinsip-prinsip yang kedudukannya lebih tinggi daripada hukum yang ditentukan manusia $^{18}$.

\section{Kualifikasi Anak dan Kedudukan Hukumnya}

UU No. 1 Tahun 1974 mengatur mengenai kedudukan anak ini dalam tiga pasal saja, yaitu Pasal 42 - Pasal 44 UU No. 1 Tahun 1974. Kedudukan dari aspek bahasa memiliki arti sebagai letak atau tempat seseorang ${ }^{19}$, dan dalam aspek hukum kedudukan anak berarti suatu posisi (status) anak dalam keluarga dan kedudukan anak ini dapat dijelaskan, sebagai berikut.

Pertama, berkaitan dengan kedudukan anak sah. Kedudukan seorang anak sebagai anak sah atau tidak sah menurut KUHPerdata, Hukum Islam dan Hukum Adat dapat dijelaskan sebagai berikut. (a) Menurut Wirjono Prodjo-

16 Sudikno Mertokusumo, 2001, Penemuan Hukum Sebuah Pengantar, Yogyakarta: Penerbit Liberty, hlm. 6-7.

17 Notoamidjojo, 1975, Soal-soal Pokok Filsafat Hukum, Jakarta Pusat: BPK Gunung Mulia, hlm. 49.

18 Abdul Ghofur Anshori, 2006, Filsafat Hukum, Yogyakarta: Penerbit Gadjah Mada University Press, hlm. 107.

19 Pusat Bahasa Departemen Pendidikan Nasional, 2001, Kamus Besar Bahasa Indonesia, Edisi Ketiga, Jakarta, Penerbit Balai Pustaka, hlm. 278. dikoro bahwa berdasar atas Pasal $255 \mathrm{KUH}$ Perdata seorang anak yang lahir setelah lampau 300 hari sesudah perkawinan terputus, adalah tidak sah (unwettig), dengan kata lain anak yang lahir dalam tengang waktu 300 hari sesudah perkawinan putus adalah anak yang sah. $^{20}$ (b) Menurut Yuynboll dalam Wirjono Prodjodikoro dikatakan bahwa menurut Hukum Islam, si anak itu supaya dapat dianggap anak dari suami ibunya, harus lahir sekurang-kurangnya enam bulan sesudah pernikahan atau di dalam tenggang iddah sesudah perkawinan putus. ${ }^{21}$ (c) Seorang anak yang lahir sesudah perkawinan putus tetapi dalam tenggang yang sama dengan tenggang hamil yang biasa (8 atau 9 bulan), tetap dianggap anak dari bekas suami ibunya. ${ }^{22}$

Kedua, berkaitan dengan kedudukan anak tidak sah. Anak tidak sah adalah anak yang dilahirkan diluar perkawinan yang sah, yang meliputi anak luar kawin, anak zinah dan anak sumbang; dan bagi anak tidak sah ini hanya mempunyai hubungan perdata dengan ibunya (Pasal 43 ayat (1) Undang Undang No. 1 Tahun 1974 Tentang Perkawinan, selanjutnya dituliskan UU no. 1 Tahun 1974). UU No. 1 Tahun 1974 menganut prinsip bahwa hubungan hukum antara anak yang dilahirkannya dengan ibunya adalah terjadi secara otomatis, artinya tidak lagi memerlukan pengakuan anak; sedangkan terhadap anak luar kawin ini hubungan hukum antara anak tersebut dengan bapak biologisnya secara yuridis harus dilakukan melalui pengakuan anak.

Fungsi pengakuan anak oleh bapak biologisnya dijelaskan oleh J. Satrio, sebagai berikut. Pertama, berdasarkan teori pembuktian (bewijsrechtelijke theorie). Pengakuan anak menimbulkan bukti adanya hubungan biologis antara si anak luar kawin dan sekaligus akan memberikan akibat hukum kepadanya dan sifat pengakuan ini adalah declaratief; dengan demikian pengakuan anak hganya dapat dilakukan

\footnotetext{
20 Wirjono Prodjodikoro, 1984, Hukum Perkawinan Di Indonesia, Bandung: Penerbit "Sumur Bandung", hlm. 78.

21 Ibid, hlm. 72

22 Ibid, hlm. 73-74.
} 
oleh orang-orang yang benar-benar "ayah" dari si anak tersebut.

Kedua, berdasarkan teori materiil (materieel rechtelijke theorie). Pengakuan anak sebetulnya merupakan tindakan hukum (rechtshandeling) yang menimbulkan hubungan darah secara hukum (juridische bloodverwantschap) antara si orang yang mengakui dengan si anak luar kawin. Disini pengakuan merupakan unsur constitutif yang menimbulkan hubungan darah dan karenanya hubungan hukum antara yang mengakui dan yang diakui ${ }^{23}$.

UU No. 1 Tahun 1974 tidak memberikan pengaturan lainnya mengenai kedudukan anak yang lahir diluar perkawinan ini, hanya di tentukan bahwa mengenai kedudukan anak tersebut pada Pasal 43 ayat (1) UU No. 1 Tahun 1974 selanjutnya akan diatur dalam Peraturan Pemerintah (Pasal 43 ayat (2) UU No. 1 tahun 1974). Sepanjang belum diterbitkan Peraturan Pemerintah, maka mengenai pengakuan anak diluar perkawinan dapat diperuntuki peraturan lama.

Ketentuan dalam KUHPerdata menjelaskan bahwa pengakuan anak yang lahir diluar perkawinan, dapat dianggap disahkan, asal ditegaskan pada waktu perkawinan dilangsungkan dan ada pengakuan dari suami isteri tersebut. Selanjutnya pengakuan anak hanya dilakukan dengan surat kawin (akta Perkawinan (Pasal 283 jo. Pasal 272 KUHPerdata), dan konsekuensi yuridisnya anak tersebut tidak hanya sebagai anak yang diakui tetapi juga menjadi anak sah. Sedangkan pengakuan anak luar kawin dapat dilakukan melalui prosedur pengadilan dengan memenuhi persyaratan harus ada pengakuan dari bapak dan ibunya (Pasal 274 KUHPerdata); dan pengakuan anak seperti ini dapat pula dilakukan dalam hal antara si bapak dan si ibu tidak dapat melakukan perkawinan, karena salah seorang dari mereka telah meninggal dunia, atau karena ada keberatan pemerintah (hukum) apabila dilakukan perkawinan di antara mereka (Pasal $275 \mathrm{KUH}$ Perdata).

23 J. Satrio, 1988, Asas Hukum Perdata, Purwokerto: Penerbit Hersa, hlm. 3-4.
Anak tidak sah dalam kualifikasi anak zinah atau anak sumbang menurut ketentuan Pasal 283 KUHPerdata pada prinsipnya terhadap mereka tidak boleh diakui, kedudukan hukum anak zinah atau anak sumbang hanya memiliki hubungan hukum dengan ibunya saja.

Penafsiran Sistematis Terhadap Konsep "Setiap Anak" Menurut UU No. 23 Tahun 2002 dengan UU No. 1 Tahun 1974 dan Peraturan Lainnya

Pasal 1 ayat (1) UU No. 23 tahun 2002 merumuskan konsep anak bukan dalam persepsi Hukum Keluarga, dan yang dimaksud "anak" adalah seseorang yang memenuhi kualifikasi belum berumur delapan belas (18) tahun termasuk anak yang masih dalam kandungan. Kemudian diatur lebih lanjut bahwa setiap anak berhak untuk mengetahui orang tuanya, di besarkan, dan diasuh oleh orang tuanya sendiri (Pasal 7 ayat (1) UU No. 23 tahun 2002). Dengan demikian telah ditentukan oleh Pembentuk Undang Undang dengan membebankan tanggung jawab tersebut kepada orang tua dari anak tersebut. Adapun yang dimaksud dengan orang tua yang harus bertanggungjawab untuk itu adalah ayah dan/atau ibu kandung, atau ayah dan/atau ibu tiri, atau ayah dan/atau ibu angkat (Pasal 1 ayat (4) UU No. 23 Tahun 2002).

Secara gramatikal berdasarkan ketentuan-ketentuan di atas dapat disimpulkan beberapa hal. Pertama, yang dimaksud dengan "anak" adalah anak sebagai subyek hukum yang dipandang belum bisa bertanggung jawab sendiri. Kedua, yang dimaksud dengan "setiap anak" adalah menunjuk pada subyek hukum dalam pengertian umum dan berlaku bagi semua anak yang memenuhi kualifikasi anak yang dimaksud oleh Undang Undang Perlindungan Anak.

Ketiga, yang dimaksud dengan "orang tua" adalah ayah dan/atau ibu kandung, atau ayah dan/atau ibu tiri, atau ayah dan/atau ibu angkat. Kemudian ditambahkannya kata "nya" dibelakang kata "orang tua" menunjuk pada konsep orang tua yang memiliki hubungan hukum keluarga dengan anak tersebut, yaitu: ayah dan/atau ibu kandung, atau ayah dan/ 
atau ibu tiri, atau ayah dan/atau ibu angkat. Dengan demikian istilah ayah dan/atau ibu kandung sementara ini bisa ditafsirkan sebagai ayah dan/atau ibu dalam konsep biologis atau ayah dan/atau ibu dalam konsep yuridis.

Keempat, yang dimaksud dengan kalimat "berhak mengetahui orang tuanya" adalah sebagai berikut, (a) kata "berhak" bermakna sebagai hak yang diberikan oleh undang undang untuk menuntut/mengajukan gugatan ke Pengadilan; dan (b) kata "mengetahui orang tuanya" bermakna sebagai memperoleh kejelasan siapa orang tuanya atau siapa ayah dan/atau ibu kandungnya. Bila demikian penafsirannya, maka kalimat "orang tuanya" dan kalimat "orang tuanya sendiri" bermakna sebagai konsep orang tua secara biologis, artinya bisa ayah kandungnya dan/atau ibu kandungnya.

Implementasi dari hak anak untuk mengetahui orang tuanya, dibesarkan dan diasuh oleh orang tuanya sendiri atas dasar Pasal 7 ayat (1) UU No. 23 tahun 2002 tersebut di atas, dengan mengingat pengertian hak dapat diartikan sebagai "sesuatu yang dapat dituntutkan atau dipertahankan kepada orang lain", kemudian mekanismenya dengan menggunakan lembaga Pengadilan dan tujuannya agar ada kejelasan status hukum anak. Selanjutnya lembaga hukum yang dapat digunakan adalah pengakuan anak, secara teoritik pengakuan anak menimbulkan bukti adanya hubungan biologis, dan sekaligus akan memberikan akibat hukum. Pengakuan anak hanya dapat dilakukan oleh orang-orang yang benar-benar "ayah" dari si anak tersebut (Teori Pembuktian), dan juga pengakuan anak merupakan tindakan hukum yang melegitimasi hubungan darah dan karenanya ada hubungan hukum antara yang mengakui dan yang diakui (Teori Materiil). Apabila pengakuan anak dilakukan oleh bukan ayah dari si anak tersebut, maka dari sudut pandang hukum berarti telah melanggar hak dari ayah biologis si anak.

Lembaga pengakuan anak ini diatur dalam KUHPerdata pada Bab Kedua belas, Bagian kedua tentang pengesahan anak-anak luar kawin dari Pasal 272 sampai dengan Pasal 289. Dikenal dua (2) macam pengakuan anak, yaitu pengakuan anak secara sukarela atas inisiatif si ayah biologis dan pengakuan anak secara terpaksa atas keputusan Pengadilan. Agaknya dalam kaitannya dengan ketentuan Pasal 7 ayat (1) UU No. 23 Tahun 2002 lembaga pengakuan anak yang dapat digunakan adalah pengakuan anak atas dasar keputusan Pengadilan, dengan pemohon adalah si anak yang mengajukan tuntutan untuk mengetahui orang tuanya.

Konsep yang digunakan dalam Pasal 7 ayat (1) UU No. 23 Tahun 2002 adalah "setiap anak" dengan demikian untuk memahaminya secara sistematis akan terhubungkan dengan kualifikasi anak. Menurut UU No. 1 tahun 1974 kualifikasi anak terdiri dari "anak sah" dan "anak tidak sah", kemudian pengertian "anak tidak sah" ini menurut KUHPerdata dikualifikasi menjadi tiga (3), yaitu: anak luar kawin, anak zinah dan anak sumbang.

Anak luar kawin adalah sebutan untuk anak yang dilahirkan di luar perkawinan yang sah dan bapak biologis serta ibu biologisnya kedua-duanya tidak terikat perkawinan (masih lajang). Pengakuan anak dapat dilakukan apabila ayah yang mengakuinya adalah ayah biologis dari si anak dan belum terikat perkawinan. Apabila si ayah biologis telah terikat perkawinan dengan perempuan lain, maka pengakuan anak tidak bisa dilakukan karena terhalang oleh perkawinannya atau terdapat kemungkinan akan merusak perkawinan si ayah biologisnya. Sedangkan anak zinah adalah anak yang lahir dari hasil hubungan zinah dalam pengertian hukum perdata, yaitu salah satu atau keduaduanya masing-masing telah terikat perkawinan sedangkan anak sumbang adalah anak yang lahir dari hasil hubungan yang dilarang oleh hukum, karena diantara bapak dan ibu biologisnya terhalang oleh larangan kawin. Terhadap anak zinah dan anak sumbang sama sekali tidak boleh diakui (Pasal 283 KUHPerdata), dengan demikian terhadap mereka tidak dapat dipergunakan lembaga pengakuan anak.

Penafsiran sistematis dalam penerapan Pasal 7 ayat (1) UU No. 23 Tahun 2002 terhadap anak tidak sah (anak luar kawin, anak zinah dan anak sumbang) harus memperhatikan bahwa dalam Hukum Keluarga dan Perkawinan me- 
miliki prinsip-prinsip dan asas-asas hukum yang bersifat khusus, dalam arti mengandung nilai yang diutamakan atas dasar untuk memelihara ketertiban dalam masyarakat. Sedangkan prinsip-prinsip dan asas-asas hukum dalam Hukum Perlindungan Anak dengan latar belakang Hak Asasi Anak, mencerminkan sifatnya yang umum. Dengan demikian penyelesaian sistemnya dalam penerapan hukum harus lebih mengutamakan prinsip-prinsip dan asas-asas hukum dalam Hukum Keluarga dan Perkawinan, agar tidak menimbulkan ketidak-tertiban dalam masyarakat dan dimungkinkan akan menghadapi resistensi yang cukup tinggi dalam masyarakat; mengingat masyarakat Indonesia masih bertumpu pada akar budaya yang komunalistis dan masih kuat penghayatan keagamaannya.

\section{Penutup \\ Simpulan}

UU No. 23 Tahun 2002 dan UU No. 1 Tahun 1974 kedua undang-undang ini sama-sama didasarkan atas asas hukum untuk memberikan perlindungan terhadap anak. UU No. 23 Tahun 2002 dilandasi asas hukum yang paling dasar, yaitu hak asasi anak sedangkan UU No. 1 Tahun 1974 dilandasai asas hukum bahwa anak perlu mendapat kepastian perlindungan hukum dengan ditetapkannya kedudukan (status hukum) seorang anak yang lahir di dalam atau sebagai akibat perkawinan yang sah.

Atas dasar itu dapat disimpulkan bahwa dengan berdasar atas prinsip-prinsip dan asasasas hukum khusus dalam Hukum Keluarga dan perkawinan yang berlaku saat ini, konsep "setiap anak" dalam Pasal 7 ayat (1) UU No. 23 Tahun 2002 tidak dapat diterapkan untuk semua kualifikasi anak tidak sah (anak luar kawin, anak zinah dan anak sumbang), dan lembaga pengakuan anak hanya dapat dipergunakan untuk anak dengan kualifikasi anak luar kawin dengan syarat ayah biologisnya tidak terikat perkawinan dengan seorang perempuan lain; agar tidak terjadi perubahan terhadap prinsipprinsip dan asas-asas hukum dalam Hukum Keluarga dan Perkawinan menjadi bersifat sangat individualistis dan sekuler.
Kontribusi tulisan ini adalah wacana bahwa implementasi HAM dalam setiap produk hukum nasional seyogyanya memperhatikan asas kepastian hukum, kemanfaatan dan keadilan, sehingga dapat memecahkan masalah masyarakat atau tidak menimbulkan masalah baru dalam masyarakat. Kemudian dalam menginterpretasi undang-undang supaya memperhatikan hakekat dari sebuah asas hukum yang memiliki peran sebagai pembentuk sistem hukum.

\section{Daftar Pustaka}

Anshori, Abdul Ghofur. 2006. Filsafat Hukum. Yogyakarta: Penerbit Gadjah Mada University Press;

Ardhiwisastra, Yudha Bhakti. 2000. Penafsiran dan Konstruksi Hukum. Bandung: Alumni;

Effendi, Masyhur. 2005. Perkembangan Dimensi Hak Asasi Manusia (HAM) dan Proses Dinamika Penyusunan Hukum Hak Asasi Manusia (HAKHAM). Bogor Selatan: Penerbit Ghalia Indonesia;

Jalal, Fasli. "Kebijakan Strategis Jangka Pendek Bidang Pendidikan Luar Sekolah Dan Pemuda Yang Berkaitan Dengan Hak Asasi Manusia". Jurnal hukum dan HAM Bidang Pendidikan. Vol. 1 No. 1. Juni 2003;

Kholid, Muhamad. "Kebijakan Formulasi Sanksi Tindakan Terhadap Anak Yang Terkait Unsur Culpa dan Tindak Pidana". Jurnal Ilmu Hukum. Vol. 1 No. 1. April 2009;

Mahendra, Oka AA. "Harmonisasi dan Sinkronisasi RUU dalam Rangka Pemantapan dan Pembulatan Konsepsi”. Jurnal Legislasi Indonesia. Vol. 2 No. 3. September 2005;

Mertokusumo, Sudikno. 1993. Bab-bab Tentang Penemu-an Hukum. Bandung: PT Citra Aditya Bakti;

...-..-. 2001. Penemuan Hukum Sebuah Pengantar. Yogyakarta: Penerbit Liberty;

Mihradi, Muhammad R. "Penegakan Hukum dan Hak Asasi Manusia". Jurnal Keadilan. Vol. 2 No. 2. Tahun 2002;

Muladi. 2005. Hak Asasi Manusia, Hakekat, Konsep dan Implikasinya Dalam Perspektif Hukum dan Masyarakat. Bandung: PT Refika Aditama; 
Notoamidjojo. 1975. Soal-soal Pokok Filsafat Hukum. Jakarta Pusat: BPK Gunung Mulia;

Nugroho, Hibnu. "Perspektif HAM dalam Pembantaran". Jurnal Dinamika Hukum. Vol. 5 No. 2. Mei 2005. Purwokerto: FH Unsoed;

Pasaribu, Bomer. "Arah Pembangunan Hukum Menurut UUD 1945 Hasil Amandemnen Dari Program Legislasi Nasional Tahun 2007". Majalah hukum Nasional. Vol. 1 No. 1 ;

Prodjodikoro, Wirjono. 1984. Hukum Perkawinan Di Indonesia. Bandung: Penerbit "Sumur Bandung";
Pusat Bahasa Departemen Pendidikan Nasional. 2001. Kamus Besar Bahasa Indonesia. Edisi Ketiga. Jakarta: Penerbit Balai Pustaka;

Satrio, J. 1988. Asas Hukum Perdata. Purwokerto: Penerbit Hersa;

Sunaryo. "Perlindungan Hukum Atas Hak Asasi Manusia Bagi Anak Dalam Proses Peradilan Pidana". Jurnal Dinamika Hukum. Vol. 2 No. 2. Mei 2005. Purwokerto: FH Unsoed;

Widjayanti, Ermania. “Aspek Hukum Perlindungan Anak". Jurnal Hukum Prioris. Vol. 1 No. 3. September 2007. 